\title{
Hematin and sulfide removal in hemolymph of the hemoglobin-containing bivalve Scapharca inaequivalvis
}

\author{
Bent Vismann \\ Marine Biological Laboratory, University of Copenhagen, Strandpromenaden 5, DK-3000 Helsingør, Denmark
}

\begin{abstract}
The hemolymph of the bivalve Scapharca inaequivalvis (Bruguière) contains in addition to hemoglobin the unusual heme compound hematin. The variation in total heme concentration in the hemolymph was best accounted for by the variation in hematin. In the hemolymph the hematin is effectively separated from the hemoglobin. The compound is present in vivo in the hemolymph. The sulfide removal in the hemolymph is high and caused only by hematin (>90\%). The results are discussed in terms of adaptations to sulfide in hemoglobin-containing invertebrates from sulfide-rich environments.
\end{abstract}

\section{INTRODUCTION}

Hydrogen sulfide is extremely toxic to aerobes because it inhibits ATP production by blocking the oxidative phosphorylation at Site III (cytochrome c oxidase) (National Research Council 1979). However, the discovery of the fauna associated with hydrothermal vents (Corliss et al. 1979) initiated a new perception of sulfide in the marine environment (reviewed e.g. by Somero et al. 1989, Fisher 1990, Vismann 1991a). It is now recognized that several species, ranging from ciliates to giant vestimentiferan worms, harbor sulfide-oxidizing bacteria as symbionts and thrive only in a mixture of oxygen and hydrogen sulfide (e.g. Cavanaugh et al. 1981, Fenchel \& Finlay 1989). During the last decade physiological adaptations in nonsymbiotic animals from sulfide-rich habitats have also been recognized. These adaptations render the species sulfide tolerant to a varying degree and thus increase the species' ecological potential (e.g. Vismann 1990). Adaptations to sulfide identified in nonsymbiotic animals include partial exclusion by sulfide trapping in external mucus layers (Giere et al. 1988), sulfide immobilization by precipitation with iron compounds (Oeschger \& Janssen 1991, Vismann 1991 b), sulfide detoxification by special pigments in the hemolymph (Patel \& Spencer 1963, Powell \& Arp
1989, Vismann 1990), and sulfide detoxification by mitochondria (Powell \& Somero 1985, Bagarinao \& Vetter 1990, Oeschger \& Vetter 1992).

Focusing on hemolymph, a sulfide-oxidizing pigment was demonstrated in the polychaete Arenicola marina by Patel \& Spencer (1963). The pigment is an oxidized heme compound, and was termed 'brown pigment'. In a study on Abarenicola affinis Wells \& Pankhurst (1980) were not able to demonstrate the presence of brown pigments and thus refuted the biological significance and in vivo presence of brown pigments. In annelids, oxidized heme compounds have been suggested to be an artifact and to occur only in individuals kept under poor laboratory conditions (Mangum 1976). However, Powell \& Arp (1989) demonstrated the presence of a pigment catalyzing sulfide oxidation in the hemolymph of healthy specimens of the echiurid Urechis caupo and of the bivalves Solemya reidi, Calyptogena magnifica, and Lucinoma annulata. Powell \& Arp (1989) showed the brown pigment to have an absorbance spectrum similar to that of oxidized (ferric) heme compounds, previously identified as hematin (Baumberger \& Michaelis 1931). Powell \& Arp (1989) concluded that the hematin present in $U$. caupo was contained in granules and not associated with proteins. The sporadic in vivo occurrence of hematin in polychaetes and bivalves from 
sulfide-rich habitats (Mangum \& Dales 1965, Powell \& Arp 1989) suggests that it is a sulfide detoxifying factor in the hemolymph of hemoglobin-containing marine invertebrates. Furthermore, the brown pigment in A. marina (Patel \& Spencer 1963) and in Nereis diversicolor (Vismann 1990) is most likely hematin, since the absorbance spectrum of hematin corresponds with the spectrophotometric analysis used in these studies (see Vismann 1990\}. Hematin has been demonstrated in several marine species belonging to different phyla, and the heme components of the hemolymph include both hematin and hemoglobin. The species shown to have hematin all live in habitats characterized by environmental sulfide.

The present study was initiated during a comparative study of anaerobic metabolism and sulfide resistance in 4 species of bivalves from the Adriatic Sea, when the distinct brown color of the hemolymph in the bivalve Scapharca inaequivalvis (Bruguière) was noticed. S. inaequivalvis is one of the few bivalve species containing hemoglobin. The hemoglobin has an oxygen half-saturation value $\left(\mathrm{p}_{50}\right)<1.3 \mathrm{kPa}$ (Weber 1990) and the species is known to be tolerant to hypoxia and anoxia (Brooks et al. 1991, de Zwaan et al. 1991). $S$. inaequivalvis is periodically exposed to hypoxia and sulfide (de Zwaan et al. 1991, Ab de Zwaan pers. comm.). The aim of the present study was to study the hemolymph of the bivalve $S$. inaequivalvis in order to reveal the presence of any hematin and to assess the activity of this compound on hydrogen sulfide.

\section{MATERIALS AND METHODS}

Scapharca inaequivalvis was collected in the Adriatic Sea $5 \mathrm{~km}$ off Bellaria, Italy, at water depths of $10 \mathrm{~m}$. At the time of collection the bottom water had a temperature of $19^{\circ} \mathrm{C}$ and a salinity of $34.2 \mathrm{ppt}$. The experiments were carried out in both Italy and Denmark. In Italy the mussels were kept in filtered seawater (temperature $=20^{\circ} \mathrm{C}, \mathrm{pH}=8.2$, salinity $=$ $35 \mathrm{ppt}$ ) aerated with atmospheric air in a large (3500 l) storage tank. Every second day about $20 \%$ of the water was exchanged. In Denmark the mussels were kept in seawater (temperature $=17^{\circ} \mathrm{C}, \mathrm{pH}=7.9$, salinity $=35 \mathrm{ppt}$ ) aerated with atmospheric air in a $50 \mathrm{l}$ tank. The mussels were fed daily with a mixture of Pavlova lutheri, Rhodomonas sp., and Isochrysis var. thahitian.

Sample preparation. The bivalves were carefully pried open and water in the mantle cavity was drained off. The blood-filled sinuses at the apices of the shells were perforated and a sample of hemolymph was taken with a pipette. Samples were immediately analyzed for heme compounds and protein.
Heme compounds. The concentration of hemoglobin was analyzed in subsamples $(100 \mu l)$ diluted $(1: 10)$ in HEPES $(10 \mathrm{mM}, \mathrm{pH}=7.5)$. The absorbances at wavelengths 500,577, and $600 \mathrm{~nm}$ were measured using a spectrophotometer (LKB, Ultrospec Plus). According to Powell \& Arp (1989), the hemoglobin concentration in a mixture of hemoglobin and hematin is proportional to the absorbance at $576 \mathrm{~nm}$ minus the absorbance at $576 \mathrm{~nm}$ calculated from a line drawn between the absorbance values at 500 and $600 \mathrm{~nm}$. The samples were compared to human hemoglobin standards using a hemoglobin kit (Sigma Diagnostics, No. 525-A) and expressed on a monomeric basis (tetrameric: dimeric ratio as in Weber 1990). In the present study the peak of hemoglobin absorbance was found at $577 \mathrm{~nm}$, instead of at $576 \mathrm{~nm}$ as found by Powell \& Arp (1989). Total heme concentration was analyzed on subsamples $(100 \mu \mathrm{l})$, which were extracted in $1 \mathrm{ml}$ acetone with $1 \%$ concentrated $\mathrm{HCl}$ for $20 \mathrm{~min}$ (Falk 1964). After extraction the samples were centrifuged at $2000 \times g$ for $2 \mathrm{~min}$. The absorbance $(635 \mathrm{~nm}$ ) of the supernatants was measured spectrophotometrically and compared to human hemoglobin standards according to the method of Powell \& Arp (1989). Hematin concentration was calculated from the concentration of hemoglobin and total heme using the formula: hematin = total heme - hemoglobin.

Total protein. The concentration of protein was assayed on $25 \mu$ laliquots using a total protein kit (Sigma Diagnostics, No. 541-2). Protein concentrations were determined at $540 \mathrm{~nm}$ using a spectrophotometer (LKB, Ultrospec Plus) and compared to human albumin/globulin standards (Sigma Diagnostics, No. 540-10).

Iron. The iron concentration was measured using atomic absorption spectrophotometry. Samples were stored at $-80^{\circ} \mathrm{C}$ until analysis. After thawing the samples $(100 \mu \mathrm{l})$ were dissolved in $2 \mathrm{ml}$ concentrated $\mathrm{HNO}_{3}$ and evaporated at $70^{\circ} \mathrm{C}$ for $24 \mathrm{~h}$ and at $150^{\circ} \mathrm{C}$ for $24 \mathrm{~h} . \mathrm{HNO}_{3}(0.2 \%)$ was added and the absorbance of the samples was measured at $248.3 \mathrm{~nm}$ using an atomic absorption spectrophotometer (Philips Unicam, PU 9200). The iron concentration of the samples was calculated from standard curves.

Hemolymph fractionation. Hemoglobin and hematin were isolated from whole hemolymph using the following procedure of Powell \& Arp (1989). The hemolymph was centrifugated twice for $5 \mathrm{~min}$ at $1000 \times g$ followed by resuspension of the pellet in a volume of filtered seawater equal to the supernatant volume. The pellet from the third centrifugation was resuspended in $10 \mathrm{mM}$ buffer (HEPES, $\mathrm{pH}=7.5$ ) and centrifugated for $20 \mathrm{~min}$ at $27000 \times \mathrm{g}$. The supernatant of this centrifugation contained the hemoglobin fraction. The pellet was washed twice by resuspension in 
buffer and centrifugation for $10 \mathrm{~min}$ at $15000 \times \mathrm{g}$. The final pellet was resuspended in buffer and contained the hematin fraction. All operations were carried out on ice and centrifugations at a temperature of $3 \pm 1{ }^{\circ} \mathrm{C}$ using a high-speed cooling centrifuge (Sigma, 3K3).

Reduced sulfur compounds. Samples were analyzed for reduced sulfur compounds using the monobromobimane technique (see e.g. Fahey \& Newton 1987, Vetter et al. 1989). Sample treatment and HPLC analysis were according to Vismann (1991b).

In vivo exposure to normoxia and hypoxia. A number of Scapharca inaequivalvis were placed in an aquarium $(30 \mathrm{l})$ containing seawater (temperature = $17^{\circ} \mathrm{C}, \mathrm{pH}=7.9$, salinity $=35 \mathrm{ppt}$ ). The mussels were allowed $1 \mathrm{~d}$ of acclimation at atmospheric oxygen tension $\left(\mathrm{p}_{\mathrm{w}} \mathrm{O}_{2}\right)$. The $\mathrm{p}_{\mathrm{w}} \mathrm{O}_{2}$ was then lowered to $2 \mathrm{kPa}$ and kept constant. After $10 \mathrm{~d}$ of exposure the hemolymph of the mussels was analyzed for heme compounds and protein. In the aquarium the $\mathrm{p}_{\mathrm{w}} \mathrm{O}_{2}$ was monitored using a Clark type oxygen electrode (Radiometer, E5047-0) connected to a pH/blood gas monitor (Radiometer, PHM 73). The $\mathrm{pH} /$ blood gas monitor was connected to a regulator (i.e. a comparator circuit), which kept the $\mathrm{p}_{w} \mathrm{O}_{2}$ at the set point. The regulator manipulated the $\mathrm{p}_{\mathrm{w}} \mathrm{O}_{2}$ via 2 magnetic valves, supplying in the open position a flow of atmospheric air or $\mathrm{N}_{2}$. The $\mathrm{p}_{\mathrm{w}} \mathrm{O}_{2}$ was continuously recorded on a Philips PM8250A recorder. In this setup the $\mathrm{p}_{\mathrm{w}} \mathrm{O}_{2}$ was controlled to $\pm 0.13 \mathrm{kPa}$. As a control the experiment was repeated without lowering the $\mathrm{p}_{\mathrm{w}} \mathrm{O}_{2}$.

In vitro sulfide exposure. Samples $(1 \mathrm{ml})$ were drawn into $10 \mathrm{ml}$ syringes containing small magnetic bars. $\mathrm{A} \mathrm{H}_{2} \mathrm{~S}$ stock solution (in $10 \mathrm{mM}$ HEPES, $\mathrm{pH}=7.5$, $\mathrm{pO}_{2}=20 \mathrm{kPa}$ ) was then drawn into the syringes giving a final sulfide concentration of $200 \mu \mathrm{M}$. Syringes added HEPES buffer instead of samples were used as a control. The syringes were sealed, placed on a magnetic stirrer and incubated. During incubation subsamples $(100 \mu l)$ were taken through the outlet of the syringes using a Hamilton $100 \mu \mathrm{l}$ syringe. The samples were analyzed for reduced sulfur compounds $\left(\mathrm{H}_{2} \mathrm{~S}, \mathrm{SO}_{3}{ }^{2-}\right.$, and $\mathrm{S}_{2} \mathrm{O}_{3}{ }^{2-}$ ). The terms sulfide and $\mathrm{H}_{2} \mathrm{~S}$ are throughout the rest of the paper referring to total sulfide (i.e. $\mathrm{H}_{2} \mathrm{~S}$, $\left.\mathrm{HS}^{-}, \mathrm{S}^{2-}\right)$.

\section{RESULTS}

\section{Hemolymph components}

The concentration of heme compounds and protein in Scapharca inaequivalvis whole hemolymph is shown in Table 1. In Fig. 1 hematin and hemoglobin are shown as a function of total heme and protein. The variation in total heme $(1.24$ to $7.20 \mathrm{mM})$ was
Table 1. Scapharca inaequivalvis. In vivo concentration of heme compounds and protein in whole hemolymph. Data: mean $\pm \mathrm{SE}$, sample number in parenthesis

\begin{tabular}{|llc|}
\hline Compound & & Concentration \\
\hline Total heme & $(\mathrm{n}=44)$ & $3.89 \pm 1.34 \mathrm{mM}$ \\
Hemoglobin & $(\mathrm{n}=44)$ & $2.23 \pm 0.95 \mathrm{mM}$ \\
Hematin & $(\mathrm{n}=44)$ & $1.66 \pm 1.25 \mathrm{mM}$ \\
Protein & $(\mathrm{n}=9)$ & $54.32 \pm 14.88 \mathrm{mg} \mathrm{ml}^{-1}$ \\
\hline
\end{tabular}

accounted for mostly by the variation in hematin (0.12 to $\left.4.41 \mathrm{mM} \mathrm{R}^{2}=0.54\right)$, but some of the variation $\left(0.77\right.$ to $\left.4.61 \mathrm{mM} ; R^{2}=0.20\right)$ was also due to hemoglobin. There was no correlation between hemoglobin and hematin $\left(\mathrm{R}^{2}=0.08\right)$ (not shown). Hemoglobin (Fig. 1D) was strongly correlated with protein $\left(\mathrm{R}^{2}=0.93\right)$ whereas hematin (Fig. 1C) was $\operatorname{not}\left(\mathrm{R}^{2}=0.08\right)$.

\section{Hemolymph fractionation}

Table 2 shows the heme and protein concentrations of whole hemolymph and of the associated isolated heme compounds; $67 \%$ of the total heme present in the hemolymph is recovered. In the isolated heme compounds 70 and $65 \%$ of the hemoglobin and hematin is recovered. The isolated heme compounds are shown in Fig. 2 as a function of protein. The relation between the heme compounds and protein in whole hemolymph (Fig. 1C, D) and in fractionated hemolymph (Fig. 2) is relatively unchanged. The hematin and hemoglobin fractions both contained iron (Table 2). This supports the hypothesis that the isolated material is hematin and that the isolation method is satisfactory (see also Fig. 3). The hematin:iron molar ratio was not different from $1: 1(0.30<p<0.40)$, but the hemoglobin:iron ratio showed a significant deviation from unity $(p<0.0001)$.

Fig. 3 shows representative absorbance spectra of whole and fractionated hemolymph. From the absorbance spectra it is evident that a mixture of compounds exists in the hemolymph (Fig. 3A) and that the fractionation procedure used is effective in separating the compounds (Fig, 3B, C).

\section{In vivo exposure to normoxia and hypoxia}

The difference in whole hemolymph components after in vivo exposure to 20 and $2 \mathrm{kPa}$ oxygen tension for $10 \mathrm{~d}$ is seen in Fig. 4. The total heme concentration increased in hypoxia $(p<0.0001)$. This increase is due solely to an increase in hemoglobin 

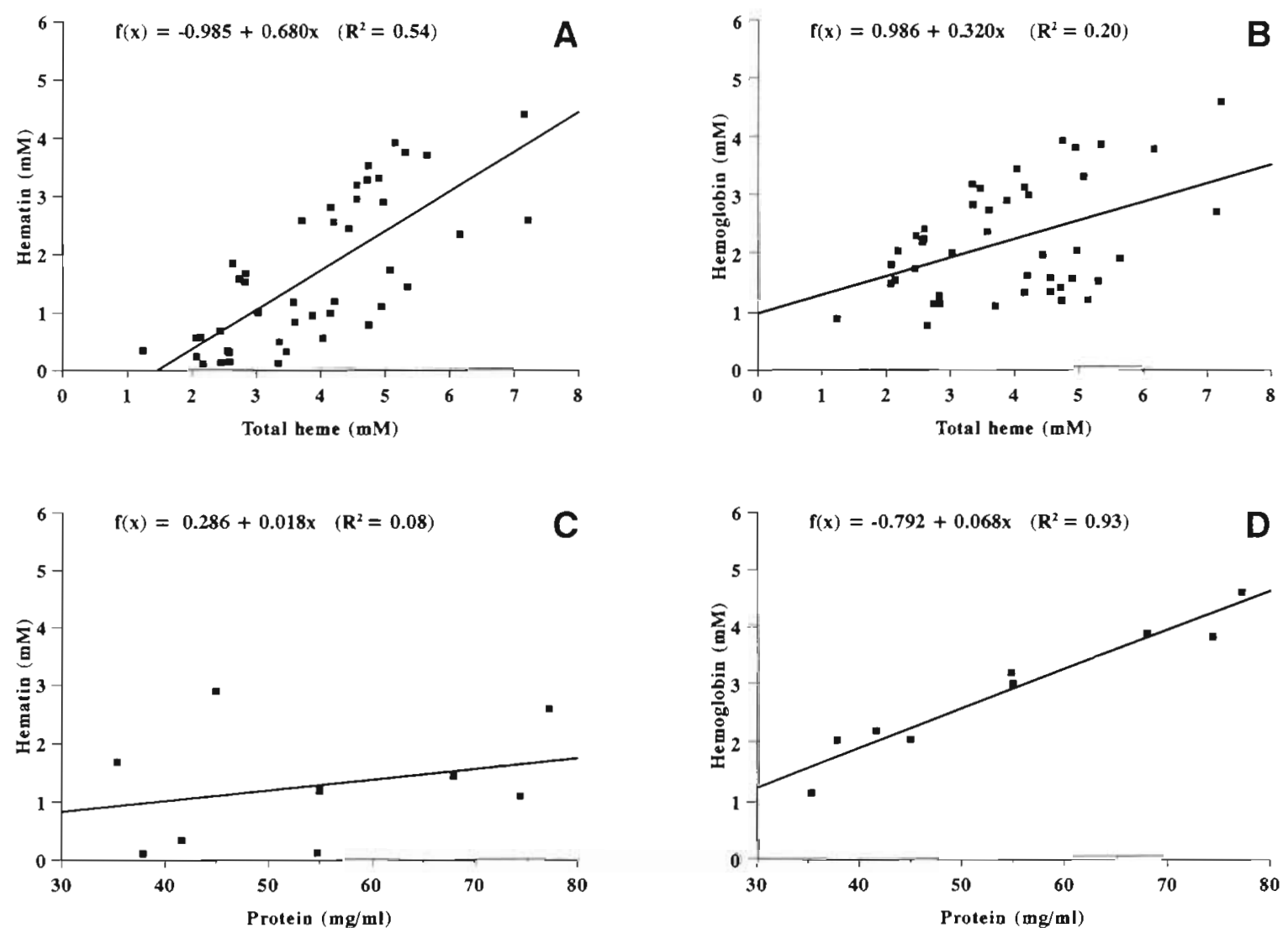

Fig. 1. Scapharca inaequivalvis. Heme compounds and protein in whole hemolymph: (A) hematin (n $=44)$ as a function of total heme; $(B)$ hemoglobin $(n=44)$ as a function of total heme; $(C)$ hematin $(n=9)$ as a function of protein; (D) hemoglobin ( $n=9)$ as a function of protein. Data presented with regression and correlation coefficients

$(p<0.0001)$. In fact, the hematin concentration decreased during hypoxia $(0.01<\mathrm{p}<0.05)$. The protein concentration also decreased significantly in hypoxia $(p<0.0001)$.

In vitro sulfide exposure. Fig. 5 shows sulfide, sulfite, and thiosulfate concentrations as a function of time in isolated hematin $(0.38 \pm 0.05 \mathrm{mM})$ and hemoglobin $(0.15 \pm 0.02 \mathrm{mM})$ incubated with sulfide $(200 \mu \mathrm{M})$. The sulfide was removed significantly only by hematin. Within $3.5 \mathrm{~min}$ the hematin removed about $150 \mu \mathrm{M}$ sulfide giving a minimum removal rate of $112.8 \mu \mathrm{M}$ sulfide $\mathrm{min}^{-1}$ (mM hematin) ${ }^{-1}$. In con- trast, the hemoglobin fraction removed only about $20 \mu \mathrm{M}$ sulfide in $12 \mathrm{~min}$, giving a removal rate of $11.1 \mu \mathrm{M}$ sulfide $\min ^{-1}$ (mM hemoglobin $)^{-1}$. Hematin was, therefore, responsible for more than $90 \%$ of the sulfide removal. The $\mathrm{SO}_{3}{ }^{2-}$ concentration remained constant in the control, tending to decrease in the hematin fraction and to increase in the hemoglobin fraction. The $\mathrm{S}_{2} \mathrm{O}_{3}{ }^{2-}$ concentration in the hematin fraction increased about $20 \mu \mathrm{M}$ in $12 \mathrm{~min}$, giving a $\mathrm{S}_{2} \mathrm{O}_{3}{ }^{2-}$ production rate of $4.4 \mu \mathrm{M}$ thiosulfate $\mathrm{min}^{-1}$ $(\mathrm{mM} \text { hematin) })^{-1}$. No $\mathrm{S}_{2} \mathrm{O}_{3}{ }^{2-}$ was produced in the hemoglobin fraction or the control.

Table 2. Scapharca inaequivalvis. In vivo concentration $(n=10)$ of heme compounds, iron, and protein in whole hemolymph and in associated isolated heme compounds. Data: mean $\pm \mathrm{SE}$

\begin{tabular}{|lccccc|}
\hline Sample & $\begin{array}{c}\text { Total heme } \\
(\mathrm{mM})\end{array}$ & $\begin{array}{c}\text { Hemoglobin } \\
(\mathrm{mM})\end{array}$ & $\begin{array}{c}\text { Hematin } \\
(\mathrm{mM})\end{array}$ & $\begin{array}{c}\text { Iron } \\
(\mathrm{mM})\end{array}$ & $\begin{array}{c}\text { Protein } \\
(\mathrm{mg} \mathrm{ml})\end{array}$ \\
\hline Whole hemolymph & $3.14 \pm 0.32$ & $1.56 \pm 0.25$ & $1.58 \pm 0.37$ & - & $66.86 \pm 6.25$ \\
Hemoglobin & $1.08 \pm 0.27$ & - & - & $0.51 \pm 0.16$ & $13.91 \pm 2.57$ \\
Hematin & $1.03 \pm 0.42$ & - & - & $0.88 \pm 0.25$ & $4.37 \pm 2.45$ \\
\hline
\end{tabular}




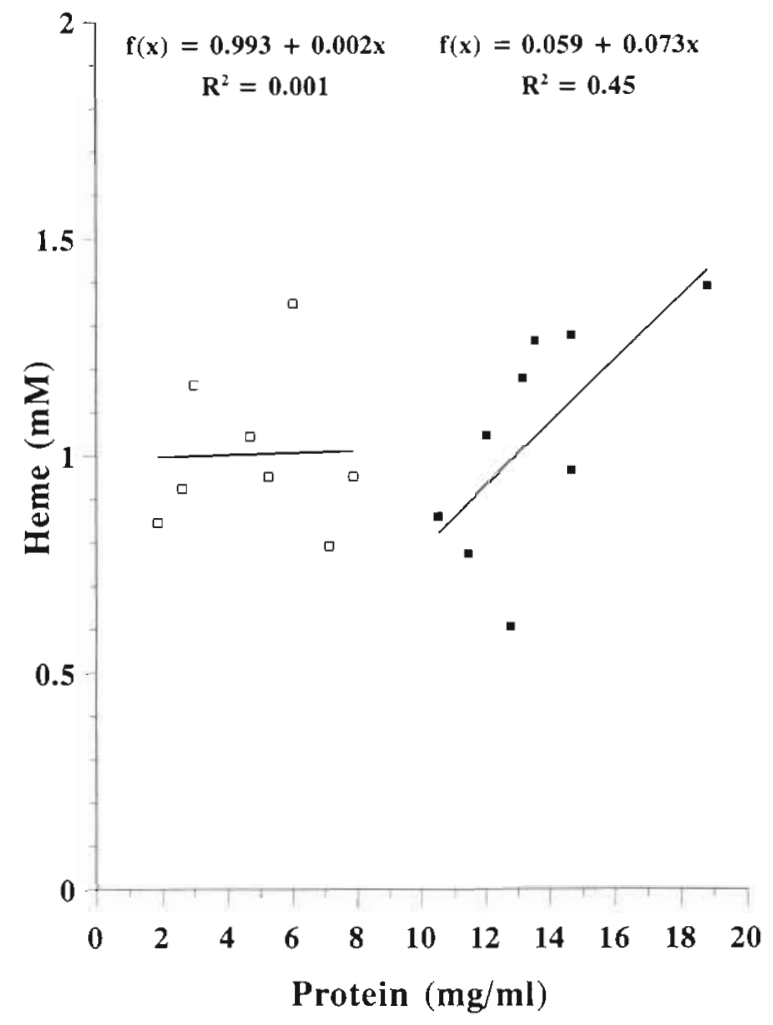

Fig. 2. Scapharca inaequivalvis. Fractionated hemolymph; (ㅁ) hematin and ( $\boldsymbol{\nabla})$ hemoglobin as a function of protein. Data presented with regression and correlation coefficients

\section{DISCUSSION}

The blood clam Scapharca inaequivalvis, a native of the Indo-Pacific (Moore 1969), was recently introduced to the Adriatic Sea where it is rapidly increasing in abundance. The 2 native species Mytilus galloprovincialis and Venus gallina in the same area are decreasing in abundance (Ghisotti \& Rinaldi 1976). The demise of native species is related to seasonal periods of low environmental oxygen concentrations (Marchetti et al. 1989). S. inaequivalvis and $M$. galloprovincialis have similar tolerance to anoxia, but $S$. inaequivalvis is superior to $M$. galloprovincialis in terms of tolerance to hypoxia, which explains the success of the former (de Zwaan et. al 1991). The tolerance to hypoxia in $S$. inaequivalvis is due to the hemoglobin-containing erythrocytes, which secure the oxygen transport and also act as an oxygen store so that the bivalve can maintain aerobic metabolism at lower $\mathrm{p}_{\mathrm{w}} \mathrm{O}_{2}$ values than is the case in the native species (Weber et al. 1990, Brooks et al. 1991, de Zwaan et. al 1991). Under these circumstances protection against hydrogen sulfide in the hemolymph might be important since sulfide is likely to be present at such low oxygen tensions.

Hematin concentrations of Scapharca inaequivalvis are comparable to those of the echiuran worm Urechis caupo (Powell \& Arp 1989). The hemoglobin corresponds to what Weber et al. (1990) found present in $S$. inaequivalvis. The relationships between hemoglobin and protein and between hematin and total heme all agree with the study by Powell \& Arp (1989). The hematin is present in vivo and is not an artifact (i.e. caused by denaturation of hemoglobin during handling). Thus there is no correlation between hemoglobin and hematin in whole hemolymph and the hemoglobin concentration is equal to what has been found in the species by Weber et al. (1990). In the fractionated hemolymph the hematin, if originating from hemoglobin, must result from a separation of heme and globin. In this case the separation of heme
Fig. 3. Scapharca inaequivalvis. Representative absorbance spectra of whole and fractionated hemolymph diluted $(1: 10)$ in HEPES $(10 \mathrm{mM}, \mathrm{pH}=7.5)$. (A) Whole hemolymph, (B) hemoglobin, and (C) hematin
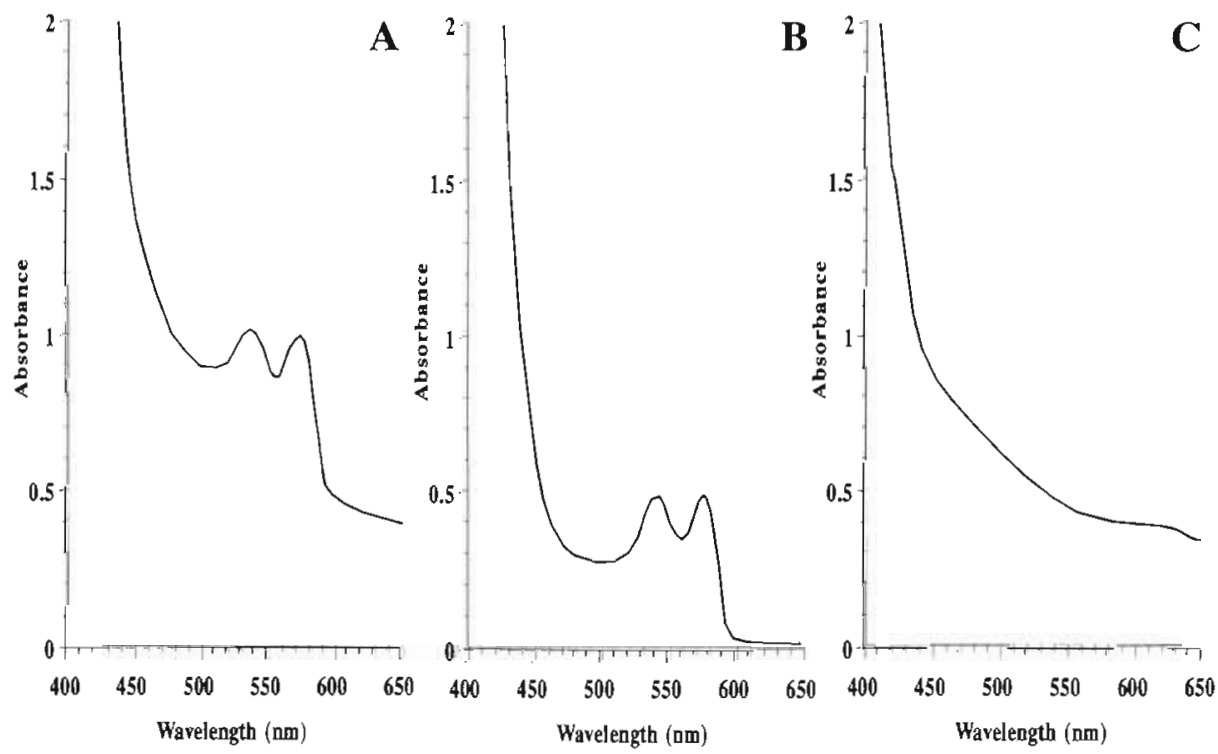


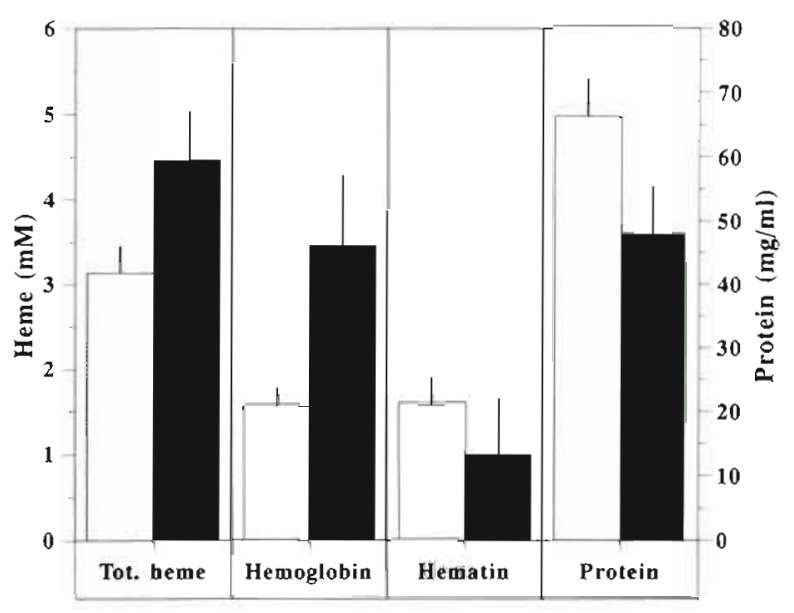

Fig. 4. Scapharca inaequivalvis. Concentration of heme compounds and protein in whole hemolymph $(n=9)$ after incubation at water oxygen tensions of 20 and $2 \mathrm{kPa}$ for $10 \mathrm{~d}$. Shaded bars $=20 \mathrm{kPa}$; solid bars $=2 \mathrm{kPa}$. Data: mean $+\mathrm{SE}$

and globin would have to take place at $\mathrm{pH}=7.5$, which according to Powell \& Arp (1989) is highly unlikely, as such separation normally requires a $\mathrm{pH}$ outside the range 2 to 12 .

In the lysate of whole hemolymph, centrifugation effectively separates hemoglobin and hematin. This shows the hematin to be associated with proteins or to be contained in granules. If hematin in Scapharca inaequivalvis is associated with proteins this dictates (at a molar ratio of $1: 1$ ) that the protein should be approximately 4200 dalton (see Table 2), or that the molar ratio be different from $1: 1$. Irrespective of the value of the molar ratio any association should turn up as a high coefficient of correlation between the 2 compounds. However, in both whole and fractionated hemolymph hematin is not correlated to protein. The present results seem to indicate that hematin is not associated with proteins. If so then the hematin must be contained in granules. This conclusion was reached in the case of Urechis caupo (Powell \& Arp 1989). However, compounds interacting with a gas (e.g. oxygen or hydrogen sulfide) are very unlikely to be contained in granules which have a minimum surface-to-volume ratio. Therefore I conclude that the hematin is most likely associated with protein at a molar ratio higher than $1: 1$. The low correlation between hematin and protein is thus most likely due to the presence of residual proteins in the pellet (i.e. proteins not associated with hematin). The hemoglobin (monomeric) molecular weight can be calculated from the isolated hemoglobin and the associated protein concentration using a heme (i.e. Fe-protoporphyrin IX) molecular weight of 615 dalton. The hemoglobin weight is in the range of 11115 to 15915 dalton, which is close to the weight of $S$. inaequivalvis hemoglobin (17 000 dalton) found by others (R. Weber pers. comm.).

The exposure to $2 \mathrm{kPa}$ oxygen for $10 \mathrm{~d}$ resulted in a significant increase in hemoglobin concentrations. This effect of hypoxia on oxygen carriers is well known (e.g. Dejours 1975). Sulfide exposure in nature occurs during periods of hypoxia. To my knowledge, a chemosensory response to oxygen and sulfide has only been studied comparatively in some ciliated protozoa, which all respond only to oxygen (Finlay et al. 1986, Fenchel \& Finlay 1989, Fenchel et al. 1989). Therefore, assuming a similar chemosensory response in Scapharca inaequivalvis, adaptation of hematin to sulfide can be expected in hypoxia. However, in the experiment the hematin decreased. Hematin is the ferric form of protoheme with an attached hydroxyl ion (Falk
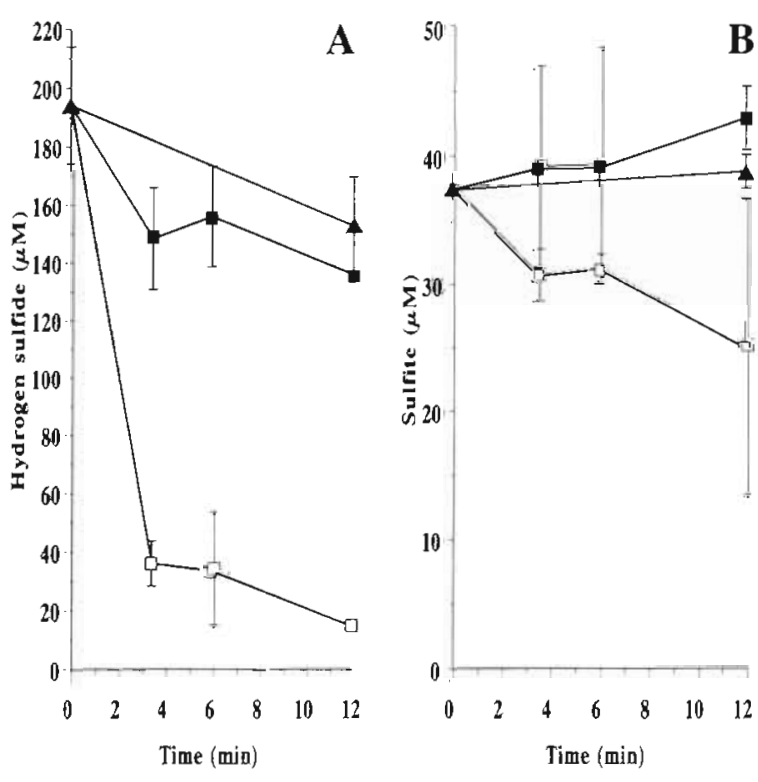

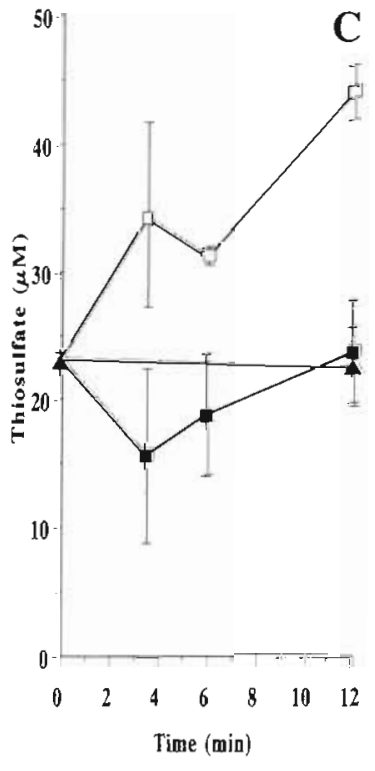

Fig. 5. Scapharca inaequivalvis. Fractionated hemolymph; hematin $(0.38 \pm$ $0.05 \mathrm{mM})$ and hemoglobin $(0.15 \pm$ $0.02 \mathrm{mM}$ ) incubated with $200 \mu \mathrm{M}$ hydrogen sulfide. Concentration of (A) hydrogen sulfide, (B) sulfite, and (C) thiosulfate as a function of incubation time. ( $\square$ ) Hematin; ( $\square$ ) hemoglobin; (4) control. Data points represent triplicates (mean $\pm \mathrm{SE}$ ) 
1964). The compound is thus likely to be involved in hemoglobin synthesis and/or degradation (either directly or as an iron storage). It should be noted that the hematin fraction will probably include other lysosomally degraded ferric iron porphyrins if present. Although the decrease in hematin during hypoxia cannot explain the increase in hemoglobin, it seems to indicate that hematin is involved in hemoglobin recycling. The decrease in hematin might, however, also reflect a too small sample size, as hematin turned out to be individually highly variable. In this context it would be very interesting to follow the change in hematin concentration after in vivo exposure to hypoxia with sulfide present. Due to lack of animals, however, this experiment awaits an impending study.

The very low sulfide removal rate of the hemoglobin shows the separation to be effective, as was also seen in the absorbance spectra analysis. The removal of sulfide by the hematin produces $\mathrm{S}_{2} \mathrm{O}_{3}{ }^{2-}$, but the majority of sulfide removed in the experiment is not recovered. In the hematin incubation only about $30 \%$ of the sulfide removed is refound as thiosulfate. The sulfide not refound might be oxidized to elemental sulfur, polysulfide, or sulfate or it can become insoluble due to binding, none of which is detectable in the HPLC analysis. The very rapid (instantaneous) initial sulfide removal strongly suggests that the greater part of the sulfide is removed by binding (to the ferric iron of hematin). The effect of hematin on sulfide thus resembles that of ferric hemoglobin (i.e. methemoglobin, which binds sulfide-forming sulfmethemoglobin (e.g. Smith \& Gosselin 1966) and also oxidizes sulfide by nonenzymatical catalysis (e.g. Baxter \& Van Reen 1958, Baxter et. al 1958, Sörbo 1958). Sulfate is produced by oxidation of $\mathrm{SO}_{3}{ }^{2-}$, which originates from a reduction of $\mathrm{S}_{2} \mathrm{O}_{3}{ }^{2-}$ (Sörbo 1964, Koj \& Frendo 1967 , Koj 1968). Therefore the $\mathrm{SO}_{3}{ }^{2-}$ decrease seen in the hematin experiment seems to indicate $\mathrm{SO}_{4}{ }^{2-}$ production. Sulfate is the major oxidation product of sulfide detoxification in terrestrial animals, but in nonsymbiotic marine animals detoxification of sulfide normally produces $\mathrm{S}_{2} \mathrm{O}_{3}{ }^{2-}$ and not $\mathrm{SO}_{4}{ }^{2-}$ (see e.g. Powell et al. 1980, Vetter et al. 1987, Bagarinao \& Vetter 1989, O'Brien \& Vetter 1990, Vismann 1991a, b, Völkel \& Grieshaber 1992). This together with the high oxygen tension of the incubations makes any $\mathrm{SO}_{4}{ }^{2-}$ production likely to be a methodological artifact.

In conclusion, hematin is shown to be present in the hemolymph of Scapharca inaequivalvis and to be an agent of sulfide removal. This offers an additional explanation for the increasing abundance of $S$. inaequivalvis in the Adriatic Sea. Further, the bivalve hematin exhibits characteristics similar to echiuran hematin. This suggests a similar mode of synthesis and function. The present study adds new evidence to the hypo- thesis that hematin is a widespread adaptation to sulfide in hemoglobin-containing invertebrates from sulfide-rich habitats. The questions of mode of synthesis and how the hematin level is controlled still need to be answered in future studies.

Acknowledgements. I thank $\mathrm{G}$. Vitali for providing the animals, $O$. Catanni and P. Cortesi for laboratory facilities in Italy, A. de Zwaan for constructive discussions, and G. Møller Christensen for supplying algae and feeding the bivalves. I am indebted to L. Hagerman for discussions and for help and advice on atomic absorption spectrophotometry. This study was supported by the Commission of the European Communities (MAST Contract No. 0044-C) and the Danish Natural Science Research Council (Contract No. 11-8391).

\section{LITERATURE CITED}

Bagarinao, T., Vetter, R. D. (1989). Sulfide tolerance and detoxification in shallow-water fishes. Mar. Biol. 103: 291-302

Bagarinao, T., Vetter, R. D. (1990). Oxidative detoxification of sulfide by mitochondria of the California killifish Fundulus parvipinnis and the speckled sanddab Citharichthys stigmaeus. J. comp. Physiol. (Sect. B) 160: 519-527

Baumberger, J. P., Michaelis, L. (1931). The blood pigments of Urechis caupo. Biol. Bull. 61: 417-421

Baxter, C. F., Van Reen, R. (1958). The oxidation of sulfide to thiosulfate by metallo-protein complexes and ferritin. Biochim. Biophys. Acta 28: 573-578

Baxter, C. F., Van Reen, R., Pearson, P. B., Rosenberg, C. (1958). Sulfide oxidation in rat tissues. Biochim. Biophys. Acta 27: $584-591$

Brooks, S. P. J., de Zwaan, A., van den Thillart, G., Cattani, O., Cortesi, P., Storey, K. B. (1991). Differential survival of Venus gallina and Scapharca inaequivalvis during anoxic stress: covalent modification of phosphofructokinase and glycogen phosphorylase during anoxia. J. comp. Physiol. (Sect. B) 161: 207-212

Cavanaugh, C. M., Gardiner, S. L., Jones, M. L., Jannasch, H. W., Waterbury: J. B. (1981). Prokaryotic cells in the hydrothermal vent tube worm Riftia pachyptila Jones: possible chemoautotrophic symbionts. Science 213: 340-342

Corliss, J. B., Dymond, J., Gordon, L. I., Edmond, J. M., von Herzen, R. P., Ballard, R. D., Green, K., Williams, D., Bainbridge, A., Crane, K., van Andel, T. H. (1979). Submarine thermal springs on Galapagos Rift. Science 203: 1073-1083

Dejours, P. (1975). Principles of comparative respiratory physiology. North Holland/Elsevier, Amsterdam

de Zwaan, A., Cortesi, P., van den Thillart, G., Roos, J., Storey, K. B. (1991). Differential sensitivities to hypoxia by two anoxia-tolerant marine molluscs: a biochemical analysis. Mar. Biol. 111: 343-351

Fahey, R. C., Newton, G. L. (1987). Determination of lowmolecular-weight thiols using monobromobimane fluorescent labeling and high-performance liquid chromatography. Meth. Enzymol. 143: 85-97

Falk, J. E. (1964). Porphyrins and metalloporphyrins. Elsevier, Amsterdam

Fenchel, T., Finlay, B. J. (1989). Kentrophoros: a mouthless ciliate with a symbiotic kitchen garden. Ophelia 30: 79-93

Fenchel, T., Finlay, B. J., Giannì, A. (1989). Microaerophily in ciliates: responses of an Euplotes species (Hypotrichida) to oxygen terision. Arch. Protistenk. 137: 317-330 
Finlay, B. J., Fenchel, T., Gardener, S. (1986). Oxygen perception and $\mathrm{O}_{2}$ toxicity in the freshwater ciliated protozoon Loxodes. J. Protozool. 33: 157-165

Fisher, C. R. (1990). Marine invertebrates and their chemolithotrophic symbionts. Rev. aquat. Sci. 2: 399-436

Ghisotti, F., Rinaldi, E. (1976). Osservazioni sulla popolazione del Scapharca insediatasi, in questi ultimi anni su un tratto di littorale romagnoto. Conchiglie (Un. malac. ital., Milano) 12: $183-195$

Giere, O., Rhode, B., Dubilier, N. (1988). Structural peculiarities of the body wall of Tubificoides benedii (Oligochaeta) and possible relations to its life in sulphidic sediments. Zoomorphology 108: 29-39

Koj, A. (1968). Enzymatic reduction of thiosulphate in preparations from beef liver. Acta biochim. polon. 15: 161-169

Koj, A., Frendo, J. (1967). Oxidation of thiosulphate to sulphate in animal tissues. Folia Biol. Cracow 15: 49-63

Mangum, C. P. (1976). Primitive respiratory adaptations. In Newell, R. C. (ed.) Adaptations to environment. Butterworths, London, p. 191-278

Mangum, C. P., Dales, R. P. (1965). Products of haem synthesis in polychaetes. Comp. Biochem. Physiol. 15: 237-257

Marchetti, R., Provini, A., Crosa, G. (1989). Nutrient load carried by the River Po into the Adriatic Sea, 1968-1987. Mar. Poll. Bull. 20: 168-172

Moore, R. C. (ed.) (1969). Treatise on invertebrate paleontology, Part N, Vol. 1, Mollusca 6, Bivalvia. The Geological Society of America, Inc., Boulder, CO, p. 1-489

National Research Council, Division of Medical Science, Subcommittee on hydrogen sulfide (1979). Hydrogen sulfide. University Press, Baltimore

O'Brien, J., Vetter, R. D. (1990). Production of thiosulphate during sulphide oxidation by mitochondria of the symbiont-containing bivalve Solemya reidi. J. exp. Biol 149: $133-148$

Oeschger, R., Janssen, H. H. (1991). Histological studies on Halicryptus spinulosus (Priapulida) with regard to environmental hydrogen sulfide resistance. Hydrobiologia 222: $1-12$

Oeschger, R. Vetter, R. D. (1992). Sulfide detoxification and tolerance in Halicryptus spinulosus (Priapulida): a multiple strategy. Mar. Ecol. Prog. Ser. 86: 167-179

Patel, S., Spencer, C. P. (1963). The oxidation of sulphide by the haem compounds from the blood of Arenicola marina. J. mar. Biol. Ass. U.K. 43: 167-175

Powell, E. N., Crenshaw, M. A., Rieger, R. M. (1980). Adaptations to sulfide in sulfide-system meiofauna. Endproducts of sulfide detoxification in three turbellarians and a gastrotrich. Mar. Ecol. Prog. Ser. 2: 169-177

Powell, M. A., Arp, A. J. (1989). Hydrogen sulfide oxidation by abundant nonhemoglobin heme compounds in marine

This article was submitted to the editor invertebrates from sulfide-rich habitats. J. exp. Zool. 249: $121-132$

Powell, M. A., Somero, G. N. (1985). Sulfide oxidation occurs in the animal tissue of the gutless clam, Solemya reidi. Biol. Bull. 169: 164-181

Smith, R. P., Gosselin, R. E. (1966). On the mechanism of sulfide inactivation by methemoglobin. Toxicol. appl. Pharmacol. 8: 159-172

Somero, G. N., Childress, J. J., Anderson, A. E. (1989). Transport, metabolism, and detoxification of hydrogen sulfide in animals from sulfide-rich marine environments. CRC crit. Rev. aquat. Sci. 1: 591-614

Sörbo, B. (1958). On the formation of thiosulfate from inorganic sulfide by liver and heme compounds. Biochim. Biophys. Acta 27: 324-329

Sörbo, B. (1964). Mechanism of oxidation of inorganic thiosulfate and thiosulfate esters in mammals. Acta chem. scand. 18: 821-823

Vetter, R. D., Matrai, P. A., Javor, B., O'Brien, J. (1989). Reduced sulfur compounds in the marine environment: analysis by high-performance liquid chromatography. Symp. Ser. Am. chem. Soc. 393: 243-261

Vetter, R. D., Wells, M. E., Kurtsman, A. L., Somero, G. N. (1987). Sulfide detoxification by the hydrothermal vent crab Bythograea thermydron and other decapod crustaceans. Physiol. Zool. 60: 121-137

Vismann, B. (1990). Sulfide detoxification and tolerance in Nereis (Hediste) diversicolor and Nereis (Neanthes) virens (Annelida: Polychaeta). Mar. Ecol. Prog. Ser. 59: 229-238

Vismann, B. (1991a). Sulfide tolerance: physiological mechanisms and ecological implications. Ophelia 34:1-27

Vismann, B. (1991b). The physiology of sulfide detoxification in the isopod Saduria (Mesidotea) entomon (L.). Mar. Ecol. Prog. Ser. 76: 283-293

Völkel, S., Grieshaber, M. K. (1992). Mechanisms of sulphide tolerance in the peanut worm, Sipunculus nudus (Sipunculidae) and in the lugworm, Arenicola marina (Polychaeta). J. comp. Physiol. (Sect. B) 162: 469-477

Weber, R. E. (1990). Effects of mercury on the functional properties of haemoglobins from the bivalve mollusc Scapharca inaequivalvis. J. exp. mar. Biol. Ecol. 144: $39-48$

Weber, R. E., Lykke-Madsen, M., Bang, A., de Zwaan, A., Cortesi, P. (1990). Effects of cadmium on anoxic survival, haematology, erythrocytic volume regulation and haemoglobin-oxygen affinity in the marine bivalve Scapharca inaequivalvis. J. exp. mar. Biol. Ecol. 144: 29-38

Wells, R. M. G., Pankhurst, N. W. (1980). An investigation into the formation of sulphide and oxidation compounds from the haemoglobin of the lugworm Abarenicola affinis (Ashworth). Comp. Biochem. Physiol. 66C: 255-259

Manuscript first received: December 17, 1992

Revised version accepted: May 27, 1993 